\title{
Vocabulary: Challenges and Debates
}

\author{
Mohammad Amiryousefi (Corresponding Author) \\ Department of English, Faculty of Foreign Languages, University of Isfahan, Isfahan, Iran
}

Tel: 98-091-3213-2381Ｅ-mail: M.Amiryousefi@Yahoo.com

\author{
Hossein Vahid Dastjerdi \\ Department of English, Faculty of Foreign Languages \\ University of Isfahan, Isfahan,Iran \\ Tel: 98-091-3318-1520 E-mail: H_Vahid@Yahoo.com
}

\begin{abstract}
Traditionally, vocabulary was neglected in language teaching programs and curriculums for the sake of grammar and other parts of language. Nowadays, however, researchers have realized that vocabulary is an important part of language learning and teaching and worthy of attention and research. A proliferation of studies done on vocabulary can be taken as a proof to it. There are, however, some core issues and principles which are scarcely touched up on in the studies done and interested researchers and language teachers are eager to know. This article, therefore, intends to first give an overview of historical approaches and methods of vocabulary learning and teaching and then to discuss some current issues which are mostly asked and discussed by young language teachers, researchers and even students.
\end{abstract}

Keywords: Vocabulary, Lexical approach, Implicit vs. Explicit learning and teaching, VLS, Vocabulary notebook, Word cards, Dictionary use

\section{Introduction}

In the literature of English language teaching and learning a recurring theme has been the neglect of vocabulary. It was often given little priority in language programs and was often left to look after itself and received only incidental attention in textbooks and language programs (Hedge, 2008; Richards and Renandya, 2002).French (1983) believes that vocabulary has been neglected in the past decades because 1) those who were involved in the teacher-preparation programs during the past few decades felt that grammar should be emphasized more than vocabulary, 2)specialists in methodology believed that students would make mistakes in sentence construction if too many words were learned before the basic grammar had been mastered, and 3)those who gave advice to teachers said that word meanings can be learned only through experience and can not be taught in the classroom. More recently, however, a number of researchers have become interested in vocabulary instruction. They have come to realize that vocabulary is an important area worthy of effort and investigation. It has, consequently, gained popularity in the general field of English language teaching and learning (Coady and Huckin, 1997; Richards and Renandya, 2002; Hedge, 2008). There is now general agreement among vocabulary specialists that it is at the heart of communicative competence (Coady and Huckin, 1997).

\section{Historical Overview}

In the early days of the Grammar Translation Method(the beginning of the ninteenth century), the primary aim of foreign language study was to learn a language in order to read its literature or to benefit from its mental discipline and intellectual development. Grammar was taught deductively and then practiced through translation studies. There was, however, no systematic way of choosing and teaching vocabulary items. They were taught through bilingual word lists, dictionary study, memorization, and their translation equivalents. Little attention was paid to the context in which they were used and the examples and sentences chosen to practice them bore no relation to the language of real communication. Having learned a new grammatical rule, the learner was expected to practice it through translation exercises from the native language into the foreign language or vice versa, using, when necessary, word lists or dictionaries. The main emphasis was on the recognition of written words and the production of written translations. The learners were mostly unable to speak or understand natural speech in the foreign language even after studying for five or six years. Later on, the same shortcoming was also ascribed to the Reading Method developed by West in the late 1920s after the publication of Coleman report. The objective of this method, as the name suggests, was to develop reading abilities and a distinction was made between intensive and extensive reading skills in the foreign language. Systematic building of vocabulary was considered central and frequency count was used to develop basic word lists. Students were encouraged to infer 
the words from the context or from the cognates in their own language. They, however, developed passive vocabulary (Chastain, 1976; Rivers, 1981; Stern, 1983; Larsen-Freeman, 2003; Richards and Rodgers, 2003).

Oppositions towards Grammar Translation Method complemented with increased opportunities for communication laid the foundation for the development of new ways of language teaching (Richards and Rodgers, 2003). During the first quarter of the century and in the late 1950s, respectively, two distinct methods, namely Direct Method and Audiolingual Method, to foreign-language teaching gradually developed to provide a remedy for the state of affairs where foreign-language learners were unable to produce and comprehend foreign-language speech. The Direct Method was based on inductive rather than deductive learning, advocating learning a new language through direct association of words and phrases with objects and actions and development of the ability to think in the language. The use of the native language was not tolerated in the classroom, and translation as a teaching technique was strictly forbidden. Concrete vocabulary was taught through mime, demonstrations, and pictures. Abstract vocabulary, on the other hand, was taught by association of ideas. Only every day vocabulary was taught. It had its own problems. It needed proficient teachers and mimicked L1 learning, but did not consider the differences between L1 and L2 acquisition (Rivers, 1981; Schmitt, 2002b; Richards and Rodgers, 2003).

American structuralism gave vocabulary its lowest status in the literature of language teaching. Systematic attention was paid to the teaching of pronunciation and sentence patterns through intensive oral drills. Vocabulary; however, was kept to its minimum to make the drills possible (Celce-Murcia, 2001; Richards and Rodgers, 2003). The Audiolingual Method, on the other hand, originated from the Army Specialized Training Program (ASTP) initiated during World War II in the United States, and possessed elements traceable both to American structuralism and to behaviorist psychology (Newton, 1979; Chastain, 1976). As indicated in its name, this approach, like the Direct Method, concentrated largely on listening and speaking skills. The techniques used to produce correct language habits in the learners were, above all, oral imitation, memorization, and drills. Vocabulary teaching, however, was kept to a useful minimum so that the students may concentrate on establishing a firm control of structures. It was assumed that exposure to language itself would lead to vocabulary learning, so no clear method of vocabulary teaching was spelled out (Rivers, 1981; Schmitt, 2002b; Larsen-Freeman, 2003; Richards and Rodgers, 2003).In 1950s Chomsky attacked the underlying theories of both behavioral psychology and American structuralism and brought about a revolutionary change in linguistic theory. His transformational generative approach recognized language as a rule governed system (Stern, 1983). Learning a language, accordingly, involved internalizing the rules (Saporta, 1966: 86). Vocabulary, however, was afforded more importance, but the focus was on rule acquisition and vocabulary was still held secondary (Celce-Murcia, 2001).

The cognitive approach to foreign-language teaching, which developed in the late 1960s, had, broadly speaking, the same teaching aims as the Audiolingual Method. Introduced by Carroll (1966), who was the first to describe a cognitive theory of language teaching, it combined elements from the Grammar Translation Method and an updated Direct Method with those of contemporary cognitive psychology. In the words of Chastain, who makes use of the competence/performance distinction introduced by Chomsky in 1965, the learner is seen as consciously acquiring competence in a meaningful manner as a necessary prerequisite in the acquisition of the "performance skills" (Chastain 1976:146). The "necessary prerequisite," in Chastain's terms, equaled a firm knowledge of the grammatical rules of the foreign language. After that, however, new sounds, structures, and vocabulary were given equal importance. Here was, in fact, a renewed interest in vocabulary, especially as far as the expansion of vocabulary knowledge for reading purposes was concerned.

In the 1970s and early 1980s, the introduction and elaboration of the concept of communicative competence first referred to by Hymes (1971) as opposed to Chomsky's "linguistic competence", had a widespread influence on the development of foreign-language teaching. Hymes rejected Chomsky's linguistic competence as being very restricted and introduced his own notion of communicative competence which he believed was much broader and incorporated sociolinguistic and contextual competence as well as grammatical competence(Hadley,2003). Once again vocabulary was given secondary position and was introduced to support functional use of language(Schmitt,2000). Such communicative approaches to foreign-language teaching were often learner-centered in nature, and stressed the importance of learning through the use of the foreign language. They generally aimed at providing learners with opportunities to interact with one another and the teacher in as "natural" situations as possible" (Widdowson, 1978; Brumfit and Johnson, 1979). Examples of such "new thought" in language pedagogy are Curran's Community Language Learnin(1972)g, Gattegno's The Silent Way(1972), and Lozanov's Suggestopedia(1979). Very promising results for vocabulary learning have been reported with Suggestopedia in particular, which combines the conscious and the unconscious in learning by 
making maximum use of the capacity of the brain (Larsen-Freeman, 2003; Richards and Rodgers, 2003).By the late 1980s and early 1990s ,however, vocabulary gained its status in language teaching and learning due to computer- aided research which provided scholars with the opportunity to analyze lexical items in different corpora, and psycholinguistics studies which gave them insights concerning mental processes involved in vocabulary learning (Celce-Murcia, 2001:286)."Evidence from large corpora(language databases) shows that there is more lexical patterning than ever imagined, and that much of what was previously considered grammar is actually constrained by lexical choices"(Schmitt,2002b:14).

\section{Lexical Approach to L2 Teaching}

The lexical approach to second language teaching has received interest in recent years as an alternative to grammar-based approaches. The lexical approach concentrates on developing learners' proficiency with lexis, or words and word combinations. It is based on the idea that an important part of language acquisition is the ability to comprehend and produce lexical phrases as unanalyzed wholes, or "chunks," and that these chunks become the raw data by which learners perceive patterns of language traditionally thought of as grammar (Lewis, 1993: 95). Instruction focuses on relatively fixed expressions that occur frequently in spoken language, such as, "I'm sorry," "I didn't mean to make you jump," or "That will never happen to me," rather than on originally created sentences (Lewis, 1997: 212). Michael Lewis, who coined the term lexical approach, suggests 1) lexis is the basis of language, 2) lexis is misunderstood in language teaching because of the assumption that grammar is the basis of language and that mastery of the grammatical system is a prerequisite for effective communication, 3 ) the key principle of a lexical approach is that "language consists of grammaticalized lexis, not lexicalized grammar", 4) one of the central organizing principles of any meaning-centered syllabus should be lexis (Lewis, 1993: 95).

\section{Current Issues}

\subsection{What to Teach}

Basic to the teaching of vocabulary is the question of what it is to know a word. It would seem to be generally accepted that lexical knowledge is best conceptualized as a continuum, between being able to recognize the sense of a word and being able to use it productively (Richards, 1979). Schmitt (1995: 86) presents a list of the word knowledge types that native speakers typically possess: 1 . a word's spoken form, 2 . a word's written form, 3. a word's part of speech, derivative forms, and grammatical patterns, 4. a word's collocations, 5. how frequently a word is used in a language, 6 . the many stylistic constrains which determine if a word is appropriate in a given context, 7. a word's conceptual meaning, 8. a word's semantic network of associations . Schmitt (1995) pictures the development of the overall knowledge of a word in the following way:

After the initial exposure, a learner may have an idea of one of the word's possible meanings, along with an impression of its form. As the learner repeatedly comes into contact with and uses the word, understanding of the word's form and meaning are strengthened, while other word knowledge aspects are generally added. This may continue until the learner finally controls the collocational and stylistic aspects. These final two kinds of word knowledge may well be the last to be controlled, since they seem to require a great deal of exposure to a language, and arguably, only a minority of L2 learners ever achieves native-like competence of these two aspects. (p. 87).

Ur (1996) similarly believes that the following aspects of a new vocabulary item must be taught to the students:1-form:pronunciation and spelling, 2- grammar: if it is regular or irregular, transitive or intransitive, its plural and singular forms etc., 3-collocation, 4- aspects of meaning : denotation, connotation, appropriateness, 5-meaning relationships: synonyms, antonyms, co- hyponyms, superordinates, translation, 6-word formation: if it can be broken down to its components (pp.60-63).

Schmitt (2002a) believes that vocabulary items; however, should be determined by two major considerations: 1-learners'needs and 2- the usefulness of the vocabulary items. In order to account for these two factors the relevant corpus is determined based on the students' needs and then the traditional frequency count can be applied to list the high frequency words which are going to be the first and main vocabulary goal of the students (pp.37-39).

\subsection{How to Teach}

\subsubsection{Implicit vs. explicit learning and teaching}

The major way in which vocabulary knowledge is increased is by learning through context. Although aural language experience is important, written language normally contains a higher proportion of difficult or low frequency words. Thus, reading is considered to be the major vehicle for continued vocabulary acquisition (Nagy, 
Herman and Anderson, 1985; Nation and Coady, 1988). There are, however, different methods of teaching and presenting words through reading texts. The first method is called incidental learning (Evelyn Hatch and Chery Brown, 1995). Coady (1997) calls it reading alone or context alone as "the first position on the continuum is labeled context alone. Other experts like Schmitt (2002) call it incidental learning. It proposes that there is actually no need of even justification for direct vocabulary instruction" (Coady, 1997: 275). This, he believes, is based on Krashen's idea (1989) that if students can comprehend the text successfully, they can learn all the words they need from the context (Coady, 1997). Nagy, Herman and Anderson (1985) argue that teachers should promote extensive reading because it can lead to greater vocabulary growth than one program of explicit instruction alone ever could. There are of course other researchers that accept the efficiency of context alone (reading alone), but they say that repeated exposures to new words are needed. Chun and Plass(1996) stated that "the research on learning words in context found only $5 \%$ to $15 \%$ probability that a given word would be learned at first exposure" (p.184). Many researchers, however, do not believe in the efficiency of context alone and call for the second method - reading plus vocabulary enhancement activities or explicit teaching of vocabulary teaching (Coady and Huckin, 1997; Schmitt, 2002b). Lyster (1990) and Swain (1988) reject the efficiency of context alone and believe that progress in this method is slow and haphazard. Nation and Coady indicate that "the very redundancy or richness of information in a given context which enables a reader to guess an unknown word successfully could also predict that the same reader is less likely to learn the word because he or she was able to comprehend the text without knowing the word" (Coady and Nation, 1988: 101). Paribakht and Wesche concluded from introspective ESL student data that most of the students ignored unknown words in reading texts unless reading comprehension questions specifically required that they be understood (Paribakht and Wesche, 1993). Schmitt and McCarthy(2005), believe that "the pendulum has swung from direct teaching of vocabulary(explicit teaching) to incidental and now, laudably, back to the middle: implicit and explicit learning"(p.239).

\subsection{Vocabulary Learning Strategies}

Vocabulary learning strategy (VLS) is an approach which facilitates vocabulary learning and has attracted considerable attention. It is a movement away from teaching- oriented approach toward one that is interested in seeing how actions of learners might affect their acquisition of vocabulary (Schmitt, 2002b).Strategies can help learners both in discovering the meaning of a word and consolidating it and are specially needed when they are encouraged to learn independently(Celce-Murcia, 2001).

\subsubsection{Guessing meaning from context}

One of the strategies commonly used is guessing word meaning from context or inferring from context. It involves learners systematically drawing on the available clues to work out the unknown words' meaning (Richards and Renandya, 2003). Richards and Renandya believe that in order to use it correctly students' confidence in guessing from context must be raised and they must be made sensitive to the clues available. Schmitt and McCarthy (2005), however, believe that a number of potential problems are associated with it. First of all learning words through guessing is very slow and students usually have a limited amount of time to learn the words they need. Secondly, it is "an error-prone process" and students, specially low -level ones, are often frustrated with it. Finally, guessing from context does not necessarily result in long-term retention.

\subsubsection{Vocabulary Notebooks and word cards}

Setting up vocabulary notebooks is a memory aid which helps the students to visualize the network of relationship between new and familiar words (Celce-Murcia, 2001).Nation (2001) believes that students become excited about the progress they make and one way to make them excited and motivated about the progress they make is to raise their awareness of how their knowledge of vocabulary is improving through effective use of vocabulary notebooks. Students can choose a loose-leaf ring binder and record the new word on the front of each page together with other information such as pronunciation, derivatives and collocations. The meaning and/or translation is recorded on the reverse side of the page. Each time they see or hear it, they can add more information like its stylistic aspects and sentences illustrating its use. To review the new words, they must first look at the front page and try to recall the recorded information on the reverse side (Ledburry, 2007). Having to retrieve the meaning results in far superior learning to seeing the word and its meaning at the same time (Baddeley, 1990). If they can not remember they can turn the page over and look at the recorded information. Learning from word cards, on the other hand, is another useful strategy which increases vocabulary size quickly (Nation, 2001).Nation, however, argues that the effectiveness of word cards is heavily dependant on the way they are used. He introduces some techniques in order to increase their efficiency. These are: 1) put the words on one side and the meaning on the other to encourage recall 2) do not put the words to each other that belong to the 
same lexical set, or are near synonyms or opposites, or are formally similar 3) keep changing the order of the cards in the pack and put difficult words near the beginning 4) at early stages see the word and try to recall the meaning, later turn over the pack, look at the meaning and try to remember the word 5) put the words in phrases or sentences or with some collocates 6) say the words aloud or to yourself. Silent repetition is not very efficient (pp.302-315).

\subsubsection{Learners' first language and dictionary use}

A strategy which is commonly reported in the literature to be used by learners is the use of first language in learning second or foreign language words. Nation (2001) mentions that research shows learning are facilitated if the meaning is in the learner's first language. The reason, according to him, is that first language meaning has already rich associations for the learner and experiment shows that both short-term and long-term retention are superior with L1 glosses. One criticism which is leveled against the use of first language in vocabulary learning is that students may think "there is a one-to-one correspondence between words in the second language and words in the first language" (p.304). Learners, therefore, need to be made aware that this is not so by drawing their attention to the underlying meanings of words. In this connection, Richards and Renandya(2002) favor bilingualized dictionaries .Bilingualized dictionaries do the job of both bilingual and monolingual dictionaries by providing L2 definitions and examples as well as L1 synonyms. One advantage is that they can be used by all types of learners. Folse(2005) believes that this type of dictionary is user-friendly and provides appealing information to a wide variety of learners.

Other useful techniques which are cited in the literature to improve vocabulary learning are: to integrate new words with the old, to provide a number of encounters with a word, to promote a deep level of processing and facilitate imaging and concreteness (verbal and non-verbal links like diagrams, pictures etc.), to arrange the words in units and stages and use a variety of techniques (Schmitt and McCarthy ,2005).

\section{Conclusion}

Vocabulary was previously neglected in the domain of language teaching and was often considered as the Cinderella sister of grammar. It was often given attention but as secondary or in short periods of time. Learning and teaching vocabulary is nowadays the center of language teaching and learning and considerable progress has been made concerning the issues related to it. There are now proliferation of activies and strategies available. The decision that language teachers and programs make as to emphasize and include which types is largely dependant on the learners' levels, needs and educational backgrounds (Richards and Rodgers, 2002).

\section{Refrences}

Baddeley, A.(1990). Human Memory. London: Lawrence Erlbaum Associates.

Brumfit, C. J. \& Johnson, K. (eds.). (1979).The Communicative Approach to Language Teaching. Oxford: Oxford University Press.

Carroll, J. (1966). The Contributions of Psychological Theory and Educational Research to the Teaching of Foreign Languages. New York: McGraw - Hill.

Celce-Murcia, M. (2001). Teaching English as a Second or Foreign Language. USA: Heinle and Heinle.

Chastain, K. (1976). Developing Second Language Skills: Theory to Practice. $2^{\text {nd }}$ ed. Chicago: Rand McNally College.

Chun, D. \& Plass, L. J. (1996). Effects of multimedia annotation on vocabulary acquisition. The Modern language Journal, 80, 183 - 195.

Coady, J. (1997). L2 Vocabulary Acquisition: A synthesis of the research. In J.Coady \& T. Huckin. Second Language Vocabulary Acquisition (pp. 225 - 237). Cambridge: Cambridge University Press.

Coady, J. \& Huckin, T. (1997). SecondLlanguage Vocabulary Acquisition. USA: Cambridge University Press Folse,K.S.(2005).Vocabulary Myths. USA: The University of Michigan Press.

French, A.V. (1983). Techniques in Teaching Vocabulary. Oxford: Oxford University Press.

Hadley, A.O. (2003). Teaching Language in Context.USA: Heinle \& Heinle.

Hatch, E. \& Brown, C. (1995). Vocabulary, Semantics and Language Education. Cambridge: Cambridge University Press.

Hedge, T. (2008). Teaching and Learning in the Language Classroom. Oxford: Oxford University Press. 
Hymes, D. (1971). On Communicative Competence. In J.B.Pride\&J.Holmes (eds.) (1971). Sociolinguistics. New York:Penguin.

Krashen, S. (1989). We acquire vocabulary and spelling by reading: Additional evidence for the output hypothesis. The Modern Language Journal, 73, 440 - 464.

Larsen-Freeman, D. (2003). Techniques and Principles in Language Teaching. $2^{\text {nd }}$ ed. Oxford: Oxford University Press.

Ledbury,R.(2007).Vocabulary Notebooks. The ILI Language Teaching Journal, 3 (1), 63-75.

Lewis, M. (1993). The Lexical Approach. Hove, England: LTP.

Lewis, M. (1997). Implementing the Lexical Approach. Hove, England: LTP.

Lyster, R. (1990). The role of analysis language teaching in French immersion programs. Canadian Modern Language Review, 47 (1), 156 - 176.

Nagy, W.E., Herman, P., \& Anderson, R.C. (1985). Learning words from context. Reading Research Quarterly, $20,233-253$.

Nation, I. S. P., \& Coady, J. (1988). Vocabulary and reading. In R. Carter \& M. McCarthy, (eds.), Vocabulary and Language Teaching (pp.97 - 110). London: Longman.

Nation, I.S.P. (2001). Learning Vocabulary in Another Language. Cambridge: Cambridge University Press.

Newton, A. C. (1979). Current trends in language teaching. In M. Celce - Murcia \& L. McIntosh (eds.) (1979). Teaching English as a Second or Foreign Language. Boston, MA. Newbury House.

Paribakht, T, \& Wesche, M. (1993). The relationship between reading comprehension - based ESL program. TESL Canada Journal,11 (1), 9 -29. In J.Coady \& T. Huckin (1997).

Richards, J. C. (1976). The role of vocabulary teaching. TESOL Quarterly,10(1): 71 - 89.

Richards, J.C. \& Renandya, W.A. (eds.) (2002). Methodology in Language Teaching: An Anthology of Current Practice. Cambridge: Cambridge University Press.

Richards, J. \& Rodgers, T. S. (2003). Approaches and Methods in Language Teaching. 2nd_ed.. Cambridge: Cambridge University Press.

Rivers, W. M. (1981). Teaching Foreign Language Skills. Chicago: The University of Chicago Press.

Saporta,S. (1966). "Applied linguistics and generative grammar" in Valdman,A.(1966). Trends in Language Teaching. New York: McGraw-Hill.

Schmitt, N. (1995). A fresh approach to vocabulary using, a word knowledge framework. RELC Journal, 26, 8694.

Schmitt, N. (2000). Vocabulary in Language Teaching. Cambridge: Cambridge University Press.

Schmitt, N. (ed.) (2002a).An Introduction to Applied Linguistics. New York: Oxford University Press.

Schmitt, N. (2002b). Vocabulary in Language Teaching.Cambridge: Cambridge University Press.

Schmitt, N \& McCarthy, M., (eds.) (2005).Vocabulary: Description, Acquisition and Pedagogy. Cambridge: Cambridge University Press.

Stern, H. H. (1983). Fundamental Concepts of LanguageTeaching. Oxford: Oxford University Press.

Swain, M. (1988). Manipulating and complementing content teaching to maximize second language learning. TESL Canada Journal, 6(1), 68 - 83.

Ur, P. (1996). A Course in Language Teaching: Practice and Theory.Cambridge: Cambridge University Press.

Widdowson, H. G. (1978). Teaching English as Communication. Oxford: Oxford University Press. 